\title{
One Century of Interactions Between Intensive Breeding and Genetic Diversity Conservation of Barley
}

\author{
Michaela BENKOVÁ ${ }^{1}$, Martina HUDCOVICOVÁ ${ }^{1}$, Lenka KLČOVÁ ${ }^{1}$, \\ Daniel MIHÁLIK ${ }^{1,2}$, Ján KRAIC ${ }^{1,2 *}$
}

\author{
${ }^{1}$ Research Institute of Plant Production, National Agricultural and Food Center, Bratislavská cesta 122, 92168 Piestany, Slovakia; \\ benkova@vurv.sk; hudcovicova@vurv.sk;.l.klcova@vurv.sk;mihalik@vurv.sk;kraic@vurv.sk(*correspondingauthor) \\ ${ }^{2}$ University of Ss. Cyril and Methodius, Faculty of Natural Sciences, Námestie J. Herdu 2, 91701 Trnava, \\ Slovakia;daniel.mihalik@ucm.sk;jan.kraic@ucm.sk
}

\begin{abstract}
The footprint left by one century of intensive breeding on the phenotype and genotype has been studied in barleys that originated and were developed at the territory of Moravia and south-western Slovakia. The set of barleys (Hordeum vulgare L.) used in retrospective analysis included 106 landraces, obsolete and modern cultivars from the period 1900-2003. The onehundred year breeding effort resulted to crucial changes of agronomic and technological parameters. The number of spikes $\mathrm{m}^{-2}$, spike density, protein and starch contents were significantly $(\mathrm{P}<0.05)$ different in new barleys (developed after the year 1972$)$. Improvement of malting quality was through decreasing of proteins (average annual decline $0.034 \%$ year ${ }^{-1}$ ) and increasing of starch (average annual gain $0.074 \%$ year $^{-1}$ ) in grains. Change in genetic diversity has been studied at 27 microsatellite loci with conclusion that nothing adverse happened at these loci during one century of breeding. The oldest barleys were heterogeneous populations, the modern ones were more homogeneous, and moreover introduction of new germplasm within the breeding process has brought new microsatellite alleles. Both, the total number of alleles and average number of alleles per locus indicated that molecular diversity was not reduced by long-term breeding. However, the average number of alleles per genotype pointed to the existence of genetic erosion caused by the gradual replacement of original landraces and local cultivars by modern cultivars. The index of genetic diversity reflected that reduction of genetic diversity from the thirties to the seventies has been turned by breeders in the eighties of the $20^{\text {th }}$ century.
\end{abstract}

Keywords: breeding, diversity, conservation, phenotype traits, microsatellite

\section{Introduction}

Barley (Hordeum vulgare L.) is grown over a broader environmental range and higher on the mountain slopes than any other cereal. Barley grains are used for feeding of animals, malt production, and as human food. Barley plants underwent intensive breeding for improvement of agronomical traits and technological parameters of grains. The direction and magnitude of changes in these characteristics were studied using different groups of barleys and by various approaches. The genetic gains obtained by the long term breeding were unambiguous (Schittenhelm et al., 1996; Abeledo et al., 2003; Rajala et al., 2016). Gain from utilizing of limited number of elite parents in crosses was high and improvement was sufficient to encourage continued breeding only within narrow gene pools, even though reduction of genetic variability has been expected. On the other side, newly generated variation made an important contribution due to the gene interactions and epistasis arised from de novo generated diversity as well as from the original diversity (Rasmusson and Phillips, 1996). Development of excellent barley cultivars was conducted also in the Central Europe, especially in Moravia (Psota et al., 2009). Barley breeding programs started there with regional barley varieties in the seventies of the $19^{\text {th }}$ century. The cultivar 'Proskowetz Hanna Pedigree' was one of the founding barleys and together with the cultivar 'Opavsky' (named also 'Kneifel', 'Kneifel barley', 'Kneifel barley-Opavsky', 'Opavský Kneifel') were later widely used in the European barley breeding programs. The barley breeding in the former Czechoslovakia (existing from 1918 to 1992) reached really an excellent level after the World War II and has been focused mainly for improvement of agronomical parameters, especially malting quality. Generally, the most important milestone was the famous cultivar 'Diamant' (Bouma, 1967) derived by mutation (X-ray irradiation) from the cultivar 'Valticky' (developed in 1950 ) with short stem and higher grain yield by $100-1040 \mathrm{~kg}$ ha $^{-1}$ (Mlčochová and Psota, 2008). 
226

One century of barley development at the territory of Moravia and south-western Slovakia has been classified by Lekeš (1997) to the six most important periods: Landrace populations and 'Hana Proskowetzův' origin (from 1882), 'Kneiflův barley-Opavsky' (from 1926), 'Valticky' (19301939), 'Diamant' (from 1965), 'Diamant's set (1972-1985), and short-stem, highly productive cultivars (after 1986). During more than one century the original barley gene pool at this territory has been enriched by new germplasm incorporated gradually into breeding programs. Original genetic diversity has been influenced positively by this flow. On the other side, the breeding goals were focused on higher yield, better malting quality and disease resistance, and higher homogeneity of new-released cultivars. Simultaneously, it started reduction of genetic diversity in barley germplasm. Changes in genetic diversity of barley germplasm caused by intensive and long-term breeding have been studied in different countries using various sets of genotypes and different methods. Some reported reduction of genetic diversity as result of the domestication (Tanksley and McCouch, 1997) and breeding (Allard, 1996; Grausguber, 2002) or genetic erosion, particularly in the last twenty years of the $20^{\text {th }}$ century (Russell et al., 2000). But, Hatz (1997) disagreed with strong narrowing of the European barley germplasm and reported that the most alleles of landraces were found also in cultivars developed later and the systematic breeding does not necessarily lead to a reduction of genetic diversity. Competition between enrichment and reduction of genetic diversity may be quantified by several approaches including phenotype and pedigree studies, variation in alleles at coding or marker loci (Matus and Hayes, 2002). Also the simple sequence repeats (SSRs) were declared as effective tool for genetic variation studies in barley (Becker and Heun, 1995; Kraic, 2005).

Development in the European barley was significantly affected by breeding in the Moravia and later also in southwestern Slovakia. More than one century interacted original barleys landraces and obsolete cultivars with introduced germplasm bringing new genes and traits. An effort of breeders also had left traces in original diversity of barley. The aim of this study was to evaluate changes in genetic diversity of barley during one century resulted from interactions with breeding and to analyse the effectiveness of genetic diversity conservation.

\section{Materials and Methods}

\section{Biological material and field trials}

The set of used barleys contained 106 genotypes of spring barley (Žáková and Benková, 2006) originated from the relatively small territory, 74 from Moravia and 32 from the south-western Slovakia. Both areas of the former Czechoslovakia are located within a radius of only about $100 \mathrm{~km}$. The oldest barley was developed in the year 1900 the newest was released 103 years later (2003). Barleys have been classified into six groups according to developmental periods defined by Lekeš (1997): group I: Haná landraces - 'Hanna Proskowetz Pedigree' (19001929, included 14 accessions - 'Dětěnický kargyn', 'Dregerův', 'Dregerův Imperial', 'Export Ratborský, 'Hanácky Kargyn', 'Hořicky', 'Jarohněvický, 'Krajová Starý Hrozenkov', 'Michalovický, 'Nolč Dregerův velerany', 'Prozkowcův', 'Stupický hanácky', 'Šumavský', 'Zborovický kargyn'), group II: 'Valticky' (1930-1940, 13 accessions - 'Diósecký kneifel',
'Hanácký exportný, 'Hanácký jubilejnỷ, 'Hanácký Moravan', 'Janovicky', 'Jindřichovický K 64', 'Kvasický, 'Novodvorský hanácky', 'Olešensky', 'Pisárecky', 'Stupický plnozrnný, 'Valticky', 'Židlochovicky'), group III: cultivars released after 1944 (1944-1964, 16 accessions - 'Bohatýr', 'Branišovický výnosnỷ, 'Bučiansky Kneifel,' 'Čelechovický hanáckỷ,' 'Diósecký sprinter', 'Diósecký 802', 'Ekonom', 'Hanácky staroveský, 'Merkur', 'Nitriansky exportný,', 'Pudmerický pivovar,', 'Semčický hospodársky', 'Semčický pivovar', 'Slovenský kvalitny', 'Terrasol pivovarsky', 'Viglašský polojemný'), group IV: 'Diamant' (19651971, 8 accessions -Denar', 'Diamant', 'Dukat', 'Dvoran', 'Jantar', 'Lutskij', 'Sladár', 'Topas'), group V: 'Diamant's set (1972-1985, 19 accessions - 'Ametyst', 'Atlas', 'Bonus', 'Diabas', 'Fatran', 'Favorit', 'Hana', 'Horal', 'Karát', 'Koral', 'Kredit 21', 'Krystal', 'Opál', 'Rapid', 'Rubín', 'Safir', 'Spartan', 'Zefir', 'Zenit'), and group VI: short-stem, highly productive cultivars (19862003, 36 accessions - 'Akcent,' 'Amos', 'Amulet', 'Atribut', 'Cyril', 'Donum', 'Expres', 'Forum', 'Galan', 'Garant', 'Granát', 'Heran', 'Jarek', 'Jaspis', 'Jubilant', 'Kompakt', 'Kosan', 'Ladík', 'Ludan', 'Malvaz', 'Novum', 'Olbram', 'Orbit', 'Pejas', 'Perun', 'Profit', 'Progres,', 'Sladko', 'Stabil', 'Svit', 'Tatry 1995', 'Terno', 'Tolar', 'Viktor,' 'Vladan', 'Zlatan').

Field trials were performed at the Experimental Station in Borovce (Research Institute of Plant Production, Slovakia) during two consecutive years. Design of the experimental plots, climatic conditions, as well as applications of fertilizers and pesticide have been published previously (Žáková and Benková, 2006).

\section{Phenotype evaluation}

Selected morphological and agronomical traits: number of spikes $\mathrm{m}^{-2}$, number of grains spike ${ }^{-1}$, weight of grains spike ${ }^{-1}$, and spike density were evaluated according to descriptor for the genus Hordeum L. (Lekeš et al., 1986; IPGRI, 1994). Content of proteins was determined by the Dumas combustion method (ISO/TS 16634-2:2009; CNS-2000, LECO Corp., USA) and starch content by the Ewers polarimetric method (ISO 10520:1997).

The correlation analysis, analysis of variance (ANOVA), and the Tukey's multiple range testing were determined using the software Statgraphic 6.1 (STSC Inc., Rockville, Maryland, USA).

\section{Microsatellite analyses}

The total DNA was extracted from equivalent amount of young leaves according to Dellaporta et al. (1993). Used primers were derived from 16 genomic microsatellites located in noncoding sequences (SSR): HVM3, HVM4, HVM40, HVM43, HVM44, HVM60, HVM68, BMS02, BMS32, Bmac0040, Bmac0067, Bmac0093, Bmac0135, Bmac0211, Bmac0223, Bmac0384 and from 11 microsatellites located in coding DNA sequences (EST-SSR): NRT22, HVWAXY, HdAMYB, Hv13GIII, HvBAMY, HvBTAI3, HvGBL2, TaCMD, HvSS1, HvPAZXG, and HvGLUEND. The EST-SSR primers were designed using the primer design software Primer3. Parameters of the polymerase chain reactions were according to Liu et al. (1996), Becker and Heun (1995), Russell et al. (1997), and Pillen et al. (2000), respectively. The PCR products were separated in $6 \%$ polyacrylamide gels denatured with urea and visualized by silver staining (Bassam and Caetano-Annolés, 1993). 
Genetic diversity at the microsatellite loci was determined by heterozygosity (Nei, 1973) and allelic richness (total number of alleles and number of alleles per genotype).

\section{Results}

\section{Changes in phenotype diversity}

The analysis of variance confirmed that the year of cultivation did not affected number of spikes $\mathrm{m}^{-2}$, number of grains spike $e^{-1}$, and weight of grains spike ${ }^{-1}$, spike density, protein content, or starch content (Table 1). On the contrary, the plant genotype statistically highly significant $(\mathrm{P}<0.001)$ affected evaluated traits except of the weight of grain spike ${ }^{-1}$. Differences between groups of barleys have been found in all six evaluated parameters. The number of spikes $\mathrm{m}^{-2}$, spike density, protein content, and starch content in groups $\mathrm{V}$ and VI were significantly $(\mathrm{P}<0.05)$ different from barleys of groups I, II, III, and IV. The average number of spikes $\mathrm{m}^{-2}$ varied between barley groups from the lowest 763 (group II, 1930-1940) to the highest value 851 (group VI, 1986-2003). The average annual gain in number of spikes $\mathrm{m}^{-2}$ during one century was 1.01 of spike $\mathrm{m}^{-2}$ year $^{-1}$ and the trend significantly $(\mathrm{P}<0.01)$ correlated with the linear increasing. The number of grains spike ${ }^{-1}$ ranged from 20.7 (group III, 1944-1964) to 22.8 (group IV, 19651971). Statistically significant improvement during one century in the number of grains spike ${ }^{-1}$ has not been proved. Similarly, improvement in grain yield during one century was not achieved by increasing of the weight of grains spike $e^{-1}$. On the contrary, the spike density has been changed statistically significant, especially during second half of the $20^{\text {th }}$ century and this trait has been developed continually from the lowest value 11.3 (group I, 1900-1929) to the highest 12.5 value (group VI, 1986-2003).
Permanent effort of breeders to improve malting quality has been demonstrated by significant decreasing (by 19.8\%) of protein content in grains. This change during one century was really outstanding. Protein content continuously decreased from $13.56 \%$ (group I, 1900-1929) to $10.88 \%$ (group VI, 1986-2003). The average annual decline in reduction of grain protein content was about $0.034 \%$ year ${ }^{-1}$ and trend during one century significantly $(\mathrm{P}<0.01)$ correlated with the linear decreasing. Other very important parameter of the malting quality, the content of starch in grain has been increased during one century continually from $57.78 \%$ (group I, 1900-1929) to $61.46 \%$ (group VI, 1986-2003) and the average progress in starch content increasing was $0.074 \%$ annually. The trend in starch content during over one century significantly $(\mathrm{P}<0.01)$ correlated with the linear increasing.

\section{Changes in microsatellite diversity}

Altogether 117 different microsatellite alleles at 27 analyzed loci have been detected. Diversity at the SSR loci was higher (62\% of all identified alleles) than at the EST-SSR (38\%). Number of different microsatellite alleles within individual groups of barleys was in range 59-97 and the highest total number of alleles was in barleys of the group VI (1986-2003). The trend curve reflecting the total number of microsatellite alleles within each group of barleys presented gain in three periods of the $20^{\text {th }}$ century (Fig. 1). The first maximum in group II (1930-1940) was due to the highest original genetic variation contained in these cultivars. The second maximum has been established in the group V (1972-1985) after the greatest allelic depression during seventies (group IV, 19651971). The third maximum was in the group VI (1986-2003) but the reason was the highest number of cultivars in this

Table 1. Phenotype traits of different genotypes of barley developed during the $20^{\text {th }}$ century, framed into six groups

\begin{tabular}{|c|c|c|c|c|c|c|c|}
\hline Period & & $\begin{array}{c}\text { Number of spikes } \\
\mathrm{m}^{-2}\end{array}$ & $\begin{array}{c}\text { Number of grains } \\
\text { spike }^{-1}\end{array}$ & $\begin{array}{c}\text { Grain weight } \\
\text { spike }^{-1}\end{array}$ & $\begin{array}{c}\text { Spike } \\
\text { density }\end{array}$ & $\begin{array}{c}\text { Protein content } \\
{[\%]} \\
\end{array}$ & $\begin{array}{c}\text { Starch content } \\
{[\%]}\end{array}$ \\
\hline \multirow{4}{*}{$\begin{array}{c}\text { Group I } \\
1900-1929\end{array}$} & Mean & $789^{6}$ & 21.5 & 0,90 & $11.3^{56}$ & $13.56^{56}$ & $57.78^{456}$ \\
\hline & Min & 724 & 17.4 & 0,74 & 10.4 & 12.78 & 52.81 \\
\hline & Max & 892 & 26.3 & 1,05 & 12.6 & 14.61 & 61.57 \\
\hline & CV\% & 5.86 & 11.79 & 12,75 & 6.02 & 4.40 & 4.72 \\
\hline \multirow{4}{*}{$\begin{array}{l}\text { Group II } \\
1930-1940\end{array}$} & Mean & $763^{56}$ & 22.1 & 0,93 & $11.6^{56}$ & $12.71^{56}$ & $59.82^{6}$ \\
\hline & Min & 628 & 16.9 & 0,72 & 11.1 & 11.11 & 57.08 \\
\hline & Max & 881 & 26.5 & 1,07 & 12.5 & 14.94 & 63.01 \\
\hline & CV\% & 8.33 & 12.17 & 10,70 & 3.56 & 7.75 & 3.12 \\
\hline \multirow{4}{*}{$\begin{array}{l}\text { Group III } \\
\text { 1944-1964 }\end{array}$} & Mean & $793^{6}$ & 20.7 & 0,92 & $11.6^{56}$ & $12.62^{56}$ & $59.67^{6}$ \\
\hline & Min & 672 & 15.5 & 0,69 & 10.7 & 9.77 & 57.00 \\
\hline & Max & 875 & 24.7 & 1,16 & 12.8 & 15.50 & 63.79 \\
\hline & CV\% & 6.77 & 12.33 & 15,18 & 4.72 & 11.55 & 2.91 \\
\hline \multirow{4}{*}{$\begin{array}{l}\text { Group IV } \\
1965-1971\end{array}$} & Mean & 807 & 22.8 & 0,98 & 11.9 & $12.27^{6}$ & 60.42 \\
\hline & Min & 764 & 20.6 & 0,82 & 10.6 & 11.30 & 59.41 \\
\hline & Max & 859 & 24.3 & 1,08 & 12.9 & 13.13 & 61.65 \\
\hline & $\mathrm{CV} \%$ & 3.89 & 5.75 & 9,01 & 6.53 & 5.31 & 1.29 \\
\hline \multirow{4}{*}{$\begin{array}{c}\text { Group V } \\
1972-1985\end{array}$} & Mean & $830^{2}$ & 22.3 & 0,91 & $12.3^{123}$ & $11.47^{23}$ & $60.49^{1}$ \\
\hline & Min & 749 & 20.3 & 0,65 & 11.0 & 10.11 & 56.07 \\
\hline & Max & 897 & 25.5 & 1,21 & 13.6 & 12.49 & 65.03 \\
\hline & CV\% & 4.92 & 5.50 & 13,96 & 5.14 & 6.37 & 3.94 \\
\hline \multirow{4}{*}{$\begin{array}{c}\text { Group VI } \\
1986-2003\end{array}$} & Mean & $851^{123}$ & 21.6 & 0,92 & $12.5^{1234}$ & $10.88^{1234}$ & $61.46^{13}$ \\
\hline & Min & 767 & 18.3 & 0,76 & 11.2 & 9.59 & 57.45 \\
\hline & Max & 905 & 26.1 & 1,08 & 15.9 & 13.49 & 66.55 \\
\hline & $\mathrm{CV} \%$ & 3.95 & 8.57 & 7,93 & 8.58 & 9.16 & 3.44 \\
\hline \multirow{4}{*}{$\begin{array}{c}\text { Groups I-VI } \\
\text { Total set }\end{array}$} & Mean & 815.9 & 21.7 & 0,92 & 12.0 & 11.94 & 60.25 \\
\hline & Min & 628 & 15.5 & 0,65 & 10.4 & 9.59 & 52.81 \\
\hline & Max & 905 & 26.5 & 1.21 & 15.9 & 15.50 & 66.55 \\
\hline & CV\% & 6.54 & 9.67 & 11.31 & 7.47 & 11.29 & 3.95 \\
\hline
\end{tabular}

Note: Superscripts reveal significant difference (Tukey's test at $5 \%$ level) from the means of groups I-IV (CV\% is the coefficient of variation) 
group. Assessment of molecular diversity using the total number of different microsatellite alleles could indicates that during one century nothing adverse happened. Modern cultivars (group VI, 1986-2003) contained the highest total number of alleles but also the highest number of analyzed genotypes. The oldest barleys were heterogeneous populations possessing higher number of alleles. On the opposite, similar total number of alleles was maintained in new cultivars only because of their much higher number. Nevertheless, introduction of diverse germplasms into long-term breeding programs enabled to generate high number of new barley cultivars containing high number of original as well as new microsatellite alleles. Also, other parameter, the average number of alleles per locus is in accordance with above-mentioned. The trend curve presenting this parameter is similar to trend in the total number of alleles. The highest value was again in barleys of the group VI (1986-2003) (Fig. 2). Both these parameters could indicate that molecular diversity was not reduced due to the long-term breeding process. However, more accurate reflection of the real situation of genetic diversity has been revealed by trend curve presenting the average number of microsatellite alleles per genotype within each of the individual groups of barleys (Fig. 2). This curve indicated a significantly adverse trend. The highest average number of alleles per genotype was identified in the group IV (1965-1971) and the lowest in the group VI (1986-2003). In contrast to previously concluded, this regression could indicate existence of genetic erosion resulted from gradual replacement of original landraces and local cultivars by modern cultivars better fulfilling requirements of barley producers. More clearly presents this fact the average number of alleles per genotype evaluated not in groups but in decades of the $20^{\text {th }}$ century. Reduction correlated highly significant $(\mathrm{P}<0.001)$ with linear decreasing (Fig. 3).

An additional parameter characterizing development in molecular diversity was the index of genetic diversity. The highest value was in the barley group II (1930-1940) then declined over the next decades, until 1985 and upward trend started in barleys of the group VI (1986-2003) (Fig. 4). It reflected trend in molecular diversity of barley during $20^{\text {th }}$ century by otherwise than both previous parameters. The trend suggests that after a significant reduction of genetic diversity from the thirties to the seventies the barley breeders turned this negative trend in the eighties and later in the $20^{\text {th }}$ century.

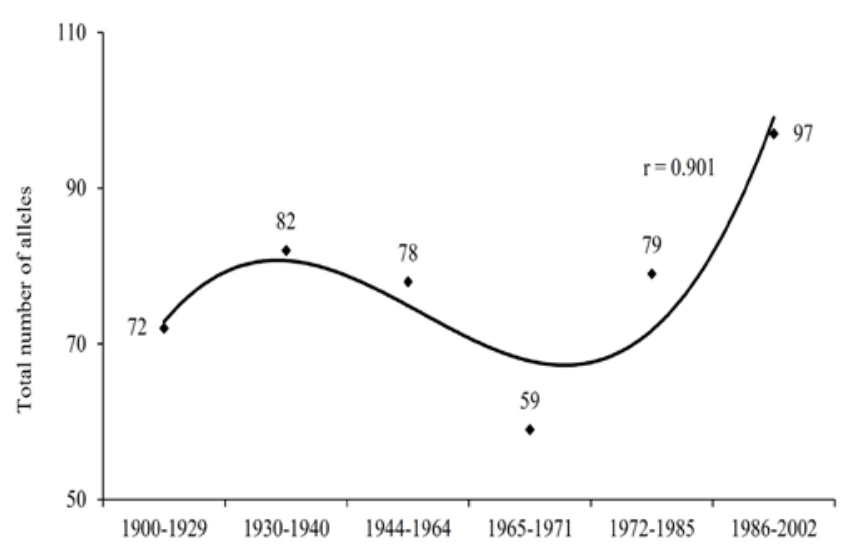

Fig. 1. Trend in the total number of microsatellite alleles in barleys during one century

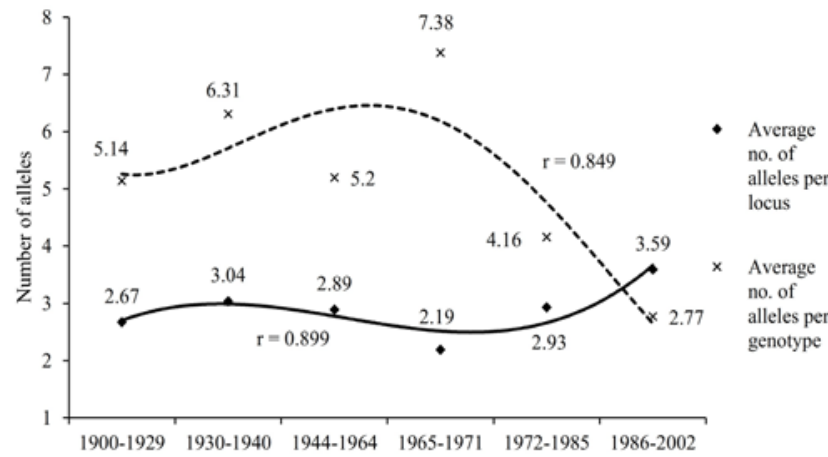

Fig. 2. Trend in the average number of alleles per locus and the average number of microsatellite alleles per genotype in barleys during one century

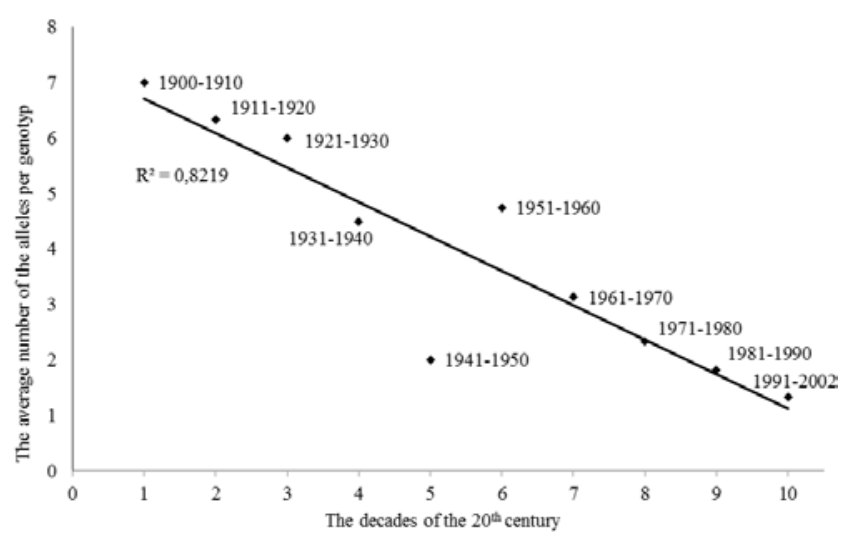

Fig. 3. The average number of alleles per genotype evaluated in decades of the $20^{\text {th }}$ century

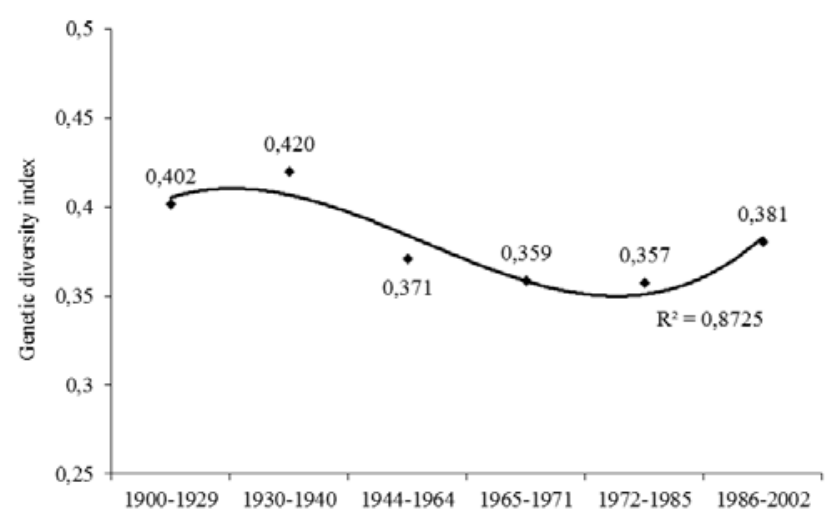

Fig. 4. Trend in the index of genetic diversity in barleys during one century

\section{Discussion}

Influence of genotype on five of evaluated phenotypic traits, including the protein and starch content was significant. It indicated that potency to change the barley genome was really in the hands of breeders. They have changed traits and parameters of plants by systematic and targeted breeding. During more than hundred years the permanent objectives of their effort have been improvements of grain yield, resistance to biotic and abiotic factors, and malting quality. Development in phenotype parameters really happened what was confirmed by comparisons between groups of barleys developed in relevant 
periods (Table 1). Positive changes in other phenotypic parameters such as spike length, plant height, weight of thousand grains, grain yield, and resistance to lodging have been confirmed previously using the same set of barleys (Záková and Benková, 2006). The greatest changes they revealed in resistance to lodging and yield of grains, both depended on reduction of the plant height. During the $20^{\text {th }}$ century the resistance to lodging has been improved by $30 \%$ and the annual average gain in resistance to lodging was $0.29 \%$ year $^{-1}$. Progress in grain yield during one century has been evident also, considering that the average annual gain in grain yield was 37 $\mathrm{kg} \mathrm{ha}^{-1}$, i.e. $0.31 \%$ year ${ }^{-1}$. Nevertheless, the basic and the most important change in barley development that affected all other traits has become in the plant height. The plant height has been reduced gradually during one century by about $19 \%$ in total and the average annual gain in reduction of plant height was $1.97 \mathrm{~mm}$ year $^{-1}$ (Žáková and Benková, 2006). Breeding process aimed to improvement of barley morphotype has been focused also to increase the number of productive tillers $\mathrm{m}^{-2}$ due to its positive effect on the plant productivity (grain yield). This approach was especially excelled in period of the Diamant-type barleys where the number of spikes $\mathrm{m}^{-2}$ created a separate component of grain yield. Significant relationships between grain yield, number of spikes $\mathrm{m}^{-2}$, and number of kernels spike $e^{-1}$ were confirmed by other authors (e.g. Ortiz et al., 2002; Li et al., 2004). According to Grausgruber et al. (2002) the genetic improvement of grain yield was the most dependent on the number of spikes per unit area. Long-term improvement of malting characteristics inevitably led to reduction of the protein content and increasing of the amount of starch in grain. Jedel and Helm (1994) detected average annual decreasing of grain protein content 0.01-0.02 $\mathrm{g} \mathrm{kg}^{-1} \mathrm{yr}^{-1}$ during over 77 years in western Canadian barley cultivars. The annual gain $0.065 \%$ in starch content in the extract detected Condón et al. (2008).

Our study of morphological, agronomical traits performed in the set of 106 barleys originated from relatively small territory of Moravia and south-western Slovakia and created within years 1900-2003 revealed significant improvement in number of spikes $\mathrm{m}^{-2}$, number of grains spike ${ }^{-1}$, and spike density.

Malting quality was improved significantly by continual increasing of starch content and decreasing of protein content. Psota and Bradová (2009) concluded that some old barley cultivars have acceptable malting quality and can be used as donors of these quantitative traits in development of new cultivars. Generally, this was not confirmed by our results, especially at the level of proteins, nevertheless existence of such specific genotypes cannot be excluded. Although the landraces and old cultivars possess a lot of negative characteristics, the historical barley genepool represents valuable source of specific and rare alleles for reselection and use in breeding and farming.

Several genetic, especially molecular genetic diversity studies in barley have submitted three conclusions related to changes in genetic diversity caused by intensive long-term breeding. According to the first, the selective plant breeding can continuously improve plant phenotype and does not need to give rise reduction of the genetic diversity. Breeding programs can effectively maintain an adequate level of genetic diversity (Koebner et al., 2003). Therefore, the level of molecular diversity in old landraces and modern cultivars could be almost equal (Backes et al., 2003; Malysheva-Otto $e t$ al., 2007; Kolodinska-Brantestam et al., 2007) and the most landrace's alleles could be found also in cultivars created by crossing in later periods (Hatz, 1997). None clear and generally applicable trends have emerged and narrowing of the genetic base of released cultivars was not observed (van de Wouw et al., 2010) by meta-analysis of the genetic diversity trends in $20^{\text {th }}$ century in several crops using molecular data.

The second conclusion is that genetic diversity has been increased during the past hundred years due to introduction of donors of biotic stress resistance (especially specific resistance genes) into breeding programs, although donors then disappeared (Milotová et al., 2008).

According to the third conclusion, selection both by breeders and farmers resulted in loss of alleles, including microsatellite alleles, in the heterogeneous breeding materials due to selection against undesirable traits linked to these alleles (Fufa et al., 2007) and the plant breeding led to a narrowing of genetic diversity (Allard, 1996; Grausguber $e t$ al., 2002; Condón et al., 2008). This was observed also within barleys grown in northern Europe where the foundation genotypes, i.e. landraces and key progenitors, contained only $72 \%$ of all microsatellite alleles and reduction of these alleles over time was detected (Russell et al., 2000).

Struss and Plieske (1998) concluded that the correlation between the allelic richness and genetic diversity need not to exist. Our results confirmed the correspondence between these parameters. However, the dynamics of increasing genetic diversity index was lower than allelic richness. The molecular data revealed changes in genetic diversity at the microsatellite loci in our study. The long-term breeding programs did not lead to deterioration of the overall allelic richness. Trend in the total number of alleles suggested that the genetic diversity remained at roughly the same level or has been increased slightly. On the other side, the average number of alleles per genotype has been decreased and this reveals the adverse trend in development of genetic diversity. Much higher number of modern cultivars possessed approximately the same total number of microsatellite alleles (but not identical alleles) as the lower number of old cultivars and landraces. It confirmed that the total reduction of genetic diversity due to long-term impact of breeding may be nonsignificant or nearly none, but alleles were diluted to a greater number of genotypes. Breeding cannot only narrow or expand genetic diversity but also shift genetic background (Fu, 2006). Population bottleneck of short duration has smaller effect on heterozygosity, but significant reduction of present alleles can be expected. Thus, the heterozygosity provides a tool for detection of ability of population to respond to selection immediately following a bottleneck (Allendorf, 1986). Trend in heterozygosity detected in our study more or less supported conservation of genetic diversity within barley after one century of intensive breeding and also overcome the short period of bottleneck from the forties to the sixties of the $20^{\text {th }}$ century (Fig. 4). This conclusion could be supported also by further outcome resulted from our study that is related to trends of loss of original alleles as well as newly appearing alleles during the one hundred years. Higher number of new alleles appeared than original alleles lost, especially in last twenty years of the $20^{\text {th }}$ century (Fig. 5). Alleles were in dynamics, relation between loss and gain of alleles remained during century positive. 


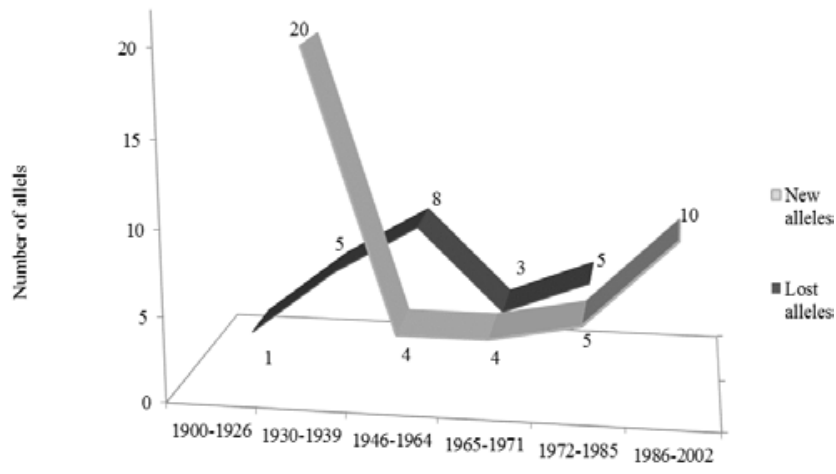

Fig. 5. The loss and intake of microsatellite alleles into barley germplasm during the $20^{\text {th }}$ century

\section{Conclusions}

Morphological, agronomical, and technological traits of barley have been during one century continually improved by long-term breeding. Obsolete, genetically more variable genotypes and landraces were replaced by more uniform cultivars. Changes were also in microsatellite diversity. The baseline level of molecular diversity that was at the beginning of the century has been decreased for about 80 years as a result of long-term breeding. However, in last two decades, an opposite trend has been detected and molecular diversity started to rise. This demonstrated that an effort of breeders led also to conservation of genetic diversity.

\section{Acknowledgements}

This work was supported by the project "Systems biology for protection, reproduction and use of plant resources of Slovakia" (code ITMS 26210120039) supported from the Operational Programme Research and Development cofinanced from the European Regional Development Fund (ERDF).

\section{References}

Abeledo LG, Calderini DF, Slafer GA (2003). Genetic improvement of barley yield potential and its physiological determinants in Argentina (1944 1998).Euphytica 130:325-334.

Allard RW (1996). Genetic basis of the evolution and adaptadness in plants. Euphytica 92:1-11.

Allendorf FW (1986). Genetic drift and the loss of alleles versus heterozygosity.Zoo Biology 5:181-190.

Backes G, Hatz B,Jahoor A, Fischbeck G (2003). RFLP diversity within and between major groups of barley in Europe. Plant Breeding 122:291-299.

Bassam BJ, Caetano-Annolés G (1993). Silver staining of DNA in polyacrylamide gels. Applied Biochemistry and Biotechnology 42:181188.

Becker J, Heun M (1995). Barley microsatellites: allele variation and mapping. Plant Molecular Biology 27:835-845.

Bouma J (1967). New variety of spring barley Diamant in Czechoslovakia. Abhandlungen der Deutschen Akademie der Wissenschaften zu Berlin, Jahrgang2:177-182.
Condón F, Gustus C, Rasmusson DC, Smith KP (2008). Effect of advanced cycle breeding on genetic diversity in barley breeding germplasm. CropScience 48:1027-1036.

Condón F, Rasmusson DC, SchiefelbeinE, VelasquezG, Smith KP (2009). Effect of advanced cycle breeding on genetic gain and phenotypic diversity in barley breedinggermplasm. Crop Science 49:1751-1761.

Dellaporta SL, Wood J, Hicks JB (1993). A plant DNA minipreparation: Version II. Plant Molecular Biology 4:19-21.

Fu Y-B (2006). Impact of plant breeding on genetic diversity of agicultural crops: searching for molecular evidence. Plant Genetic ResourcesCharacterization and Utilization 4:71-78.

Fufa F, Baum M, Grando S, Kafawin O, Ceccarelli S (2007). Consequences of a decentralized participatory barley breeding programe on changes in SSR allele frequency and diversity in one cycle of selection. Plant Breeding 126:527-532.

Grausgruber H, Bointner H, Tumpold R, Rückenbauer P (2002). Genetic improvement of agronomic and qualitative traits of spring barley. Plant Breeding 121:411-416.

Hatz B (1997). Untersuchungen der genetischen Diversität innerhalb der Gattung Hordeum mit molekularen Markertechniken [Investigations of genetic diversity within the genus Hordeum with molecular marker techniques].PhD Thesis, Technische Univesität, München.

IPGRI (1994). Descriptors for barley (Hordeum vulgare L.). International Plant Genetic Resources Institute, Roma.

ISO 10520:1997 (1997). Native starch - Determination of starch content Ewers polarimetric method.

ISO/TS 166342:2009 (2009). Food products - Determination of the total nitrogen content by combustion according to the Dumas principle and calculation of the crude protein content - Part 2: Cereals, pulses and milled cereal products.

Jedel PE, Helm JH (1994). Assessment of western Canadian barleys of historical interest: I. Yield and agronomic traits. Crop Science 34: $922-$ 927.

Koebner RMD, Donini P, Reeves JC, Cooke RJ, Law JR (2003). Temporal flux in the morphological and molecular diversity of UK barley. Theoretical and Applied Genetics 106:330-558.

Kolodinska-Brantestam A, von Bothmer R, DaytegC, Rashal I, Tuvesson S, Weibull J (2007). Genetic diversity changes and relationships in spring barley (Hordeum vulgare L.) germplasm of Nordic and Baltic areas as shown by SSR markers. Genetic Resources and Crop Evolution 54:749758.

Kraic J (2005). Relevancy of genomic and gene-based variation in distinguishing of elite barleys. Biologia 60:675-680.

Lekeš J (1997). Šlechtění obilovin na území Československa [Cereals Breedingin the Czechoslovakia].Plant Select, Brázda, Praha.

LekešJ,ZezulováP, BarešI,SehnalováJ, Vlasák M (1986). Klasifikátor, genus Hordeum L. [Classificator of the Genus Hordeum L.]. VÚRV, Praha.

Li YC, Korol AB, Fahima T, Nevo E (2004). Microsatellites within genes: structure, function and evolution. Molecular Biology and Evolution 21:991-1007.

Liu ZW, Biyashev RM, Saghai MaroofMA (1996). Development of simple sequence repeat DNA markers and their integration into a barley linkage map. Theoretical and Applied Genetics 93:869-876. 
Malysheva-Otto L, Ganal MW, Law JR, Reeves JC, Röder MS (2007). Temporal trends of genetic diversity in European barley cultivars (Hordeum vulgare L.). Molecular Breeding 20:309-322.

Matus IA, Hayes PM (2002). Genetic diversity in three groups of barley germplasm assessed by simple sequence repeats. Genome 45:1095-1106.

Milotová J, Martynov SP, Dobrotvorskaya TV, Vaculová K (2008). Genealogical analysis of the diversity of spring barley cultivars released in former Czechoslovakia and modern Czech Republic. Russian Journal of Genetics 44:51-59.

Mlčochová L, Psota V (2008). Molecular analysis and malting quality of spring barley varieties (Hordeum vulgare L.) Valtický and Diamant. KvasnýPrůmysl 54:6-13.

Nei M (1973). Analysis of gene diversity in subdivided populations. Proceedings of the National Academy of Sciences of the USA 70:33213323.

Ortiz R, Nurminiemi M, Madsen S, Rognli OA, Bjørnstad Å (2002). Genetic gains in Nordic spring barley breeding over sixty years. Euphytica 126:283-289.

Pillen K, Binder A, Kreuzkam B, Ramsay L, Waugh R, Förster J, Léon J (2000). Mapping of new EMBL-derived barley microsatellites and their use in differentiation of German barley cultivars. Theoretical and Applied Genetics 101:652-660.

Psota V, Hartmann J, SejkorováŠ, Loučková T, Vejrazka K(2009). 50 Years of progress in quality of malting barley grown in the Czech Republic. Journal of the Institute of Brewing 115:279-291.

Psota V, Bradová J (2009). Historical varieties of spring barley (Hordeum vulgare $\mathrm{L}$.) and their use as genetic resources of malting quality. Agriculture 55:2-9.
Rajala A, Peltonen-Sainio P, Jalli M, Jauhiainen L, Hannukkala A, TenholaRoininen T, Ramsay L, Manninen O (2016). One century of Nordic barley breeding: nitrogen use efficiency, agronomic traits and genetic diversity. Journal of Agricultural Science. doi:10.1017/S002185 961600068X

Rasmusson DC, Phillips RL (1996). Plant breeding progress and genetic diversity from de novo variation and elevated epistasis. Crop Science 37:303-310.

Russell JR, Ellis RP, Thomas TB, Waugh R, Provan J, Booth A, Fuller J, Lawrence P, Young G, Powell W (2000). A retrospective analysis of spring barley germplasm development from "foundation genotypes" to currently successful cultivars. Molecular Breeding 6:553-568.

Schittenhelm S, Okeno JA, Friedt W (1996). Prospects of agronomic improvement in spring barley based on a comparison of old and new germplasm. Journal of Agronomy and CropScience 176:295-303.

Struss D, Plieske J (1998). The use of microsatellite markers for detection of genetic diversity in barley populations. Theoretical and Applied Genetics 97:308-315.

Tanksley SD, McCouch SR (1997). Seed banks and molecular maps: unlockinggenetic potential from the wild. Science 277:1063-1066.

van de Wouw M, van Hintum T, Kik C, van Treuren R, Visser B (2010). Genetic diversity trends in twentieth century crop cultivars: a metaanalysis. Theoretical and Applied Genetics 120:1241-1252.

Žáková M, Benková M (2006). Characterization of spring barley accessions based on multivariate analysis. Communications in Biometry and Crop Science 1:124-134. 